\title{
Characterization of Some Caprine Mycoplasmas, with Proposals for New Species, Mycoplasma capricolum and Mycoplasma putrefaciens
}

\author{
By J. G. TULLY,* M. F. BARILE, $\dagger$ D. G. FF. EDWARD, \\ T.S. THEODORE§ AND H. ERNØ
}

(Received 2I January I974; revised 6 June 1974)

\begin{abstract}
SUMMARY
Of a group of unclassified, mostly caprine mycoplasmas, six were antigenically related to one another, possessed similar biochemical and biological properties and were antigenically distinct from all other human and animal Mycoplasmatales. It is proposed that this group of mycoplasmas be established as a new species within the Mycoplasmatales. One additional isolate, of questionable host origin, was also antigenically distinct from other Mycoplasmatales and is proposed as another new species. The identification of mycoplasmas originally recovered from porcine and caprine hosts as Mycoplasma mycoides subsp. mycoides supports recent evidence that this subspecies occurs in animals other than cattle. The results emphasize the importance of using proper type strains of $M$. mycoides subsp. mycoides and $M$. mycoides subsp. capri in serological identification of mycoplasmas recovered from animal hosts.
\end{abstract}

\section{INTRODUCTION}

An understanding of the mycoplasmal flora of goats has been complicated by a number of problems, the most notable being the incomplete characterization of the large number of mycoplasmas recovered and a long running dispute about the identity, serological characteristics and classification of various mycoplasmas involved in contagious caprine pleuropneumonia (Cottew \& Leach, 1969). However, there has been some clarification of the distinctive mycoplasmal flora of goats. At present, five fully characterized and named Mycoplasma and one Acholeplasma species have been identified in goats (Edward, I954, I955; Edward \& Freundt, 1956, 1973; Barile et al. I968; Barile, Del Giudice \& Tully, 1972; Al-Aubaidi, Dardiri, Muscoplatt \& McCauley, 1973). Numerous other unclassified caprine mycoplasmas have been isolated, several of which have been implicated in specific diseases in this animal (Cottew \& Leach, 1969). However, information adequate to document these strains as distinct species or confirm any pathological properties is not yet available.

This study was prompted by some observations on the close interrelationships of several unclassified caprine mycoplasmas to two other isolates originally thought to be of human origin. All of the mycoplasmas within this group were clearly distinct from other human and animal Mycoplasma and Acholeplasma species by conventional serological tests. Their

* Laboratory of Infectious Diseases, National Institute of Allergy and Infectious Diseases, Rethesda, Maryland 20014, U.S.A.

$\dagger$ Bureau of Biologics, Food and Drug Administration, Rockville, Maryland 20852, U.S.A.

† Public Health Laboratory, Dulwich Hospital, East Dulwich Grove, London, S.E. 22.

$\S$ Laboratory of Microbiology, National Institute of Allergy and Infectious Diseases, Bethesda, Maryland 20014 , U.S.A.

II Institute of Medical Microbiology, University of Aarhus, Denmark. 
Table I. Mycoplasmas used in the study

\begin{tabular}{|c|c|c|c|c|}
\hline Mycoplasma & $\begin{array}{c}\text { Strain } \\
\text { designation }\end{array}$ & $\begin{array}{l}\text { Animal host and } \\
\text { recovery site }\end{array}$ & $\begin{array}{l}\text { Geographic } \\
\text { origin }\end{array}$ & Source \\
\hline $\begin{array}{l}\text { M. mycoides } \\
\text { subsp. mycoides } \\
\text { M. mycoides }\end{array}$ & PGI & Cattle & Unknown & E. A. Freundt \\
\hline subsp. capri & PG3 & Goat - pleural fluid & Turkey & D. G. ff. Edward \\
\hline Mycoplasma sp. & B3 & Swine - nasal cavity & Sweden & Z. Dinter \\
\hline Mycoplasma sp. & UM30847 & Goat & U.S.A. (Maryland) & R. H. Purcell \\
\hline Mycoplasma sp. & pp goat & Goat & Turkey & $\begin{array}{l}\text { Mycoplasma Refer- } \\
\text { ence Laboratory, } \\
\text { London }\end{array}$ \\
\hline Mycoplasma sp. & California goat & Goat - joint & U.S.A. (California) & H. C. Neimark \\
\hline Mycoplasma sp. & $\begin{array}{l}\text { California kid } \\
\text { (ATCC27343) }\end{array}$ & Goat - joint & U.S.A. (California) & ATCC \\
\hline Mycoplasma sp. & $\begin{array}{l}\text { Strain I4 } \\
\text { (ATCC27342) }\end{array}$ & Goat - joint & U.S.A. (California) & ATCC \\
\hline Mycoplasma sp. & $\begin{array}{l}4330 Y \\
(\text { ATCC23205) }\end{array}$ & Man? & $\begin{array}{l}\text { U.S.A. } \\
\text { (Massachusetts) }\end{array}$ & ATCC \\
\hline Mycoplasma sp. & Campo D & Man? & $\begin{array}{l}\text { U.S.A. } \\
\text { (Massachusetts) }\end{array}$ & D. G. ff. Edward \\
\hline Mycoplasma sp. & KSI (ATCCI 57I8) & Goat? & U.S.A. (California) & ATCC \\
\hline $\begin{array}{l}\text { Mycoplasma sp. } \\
\text { M. agalactiae }\end{array}$ & Goat I 45 & Goat - joint lesion & U.S.A. (Maryland) & R. A. Del Giudice \\
\hline subsp. agalactiae & PG2 & Sheep & Spain & E. A. Freundt \\
\hline M. arginini & G230 (ATCC23838) & Mouse - brain & U.S.A. (Maryland) & M. F. Barile \\
\hline $\begin{array}{l}\text { M. conjunctivae } \\
\text { Acholeplasma }\end{array}$ & $\mathrm{HRC}_{5} 8 \mathrm{I}(\mathrm{ATCC} 25834)$ & Sheep - pink eye & U.S.A. (Maryland) & M. F. Barile \\
\hline oculusi & $19 \mathrm{~L}$ & Goat - eye & U.S.A. (Minnesota) & J. M. Al-Aubaidi \\
\hline
\end{tabular}

biological and serological characteristics are presented here along with a proposed species designation. In addition, another mycoplasma isolated I 6 years earlier and initially thought to be of caprine origin has been identified as another distinct Mycoplasma species.

\section{METHODS}

Mycoplasmas. The strain designation, geographic origin, and other pertinent information are given in Table I. Investigations on three mycoplasmas (the two Mycoplasma mycoides subspecies and $M$. agalactiae subsp. agalactiae) were carried out in England or Denmark since work on these organisms is prohibited under present U.S.A. quarantine regulations. All mycoplasmas were cloned at least three times by picking single colonies from agar plates inoculated with a $24 \mathrm{~h}$ broth culture filtered through a $220 \mathrm{~nm}$ membrane filter.

Media and growth conditions. All mycoplasmas were grown aerobically at $37^{\circ} \mathrm{C}$ on a fluid medium containing Mycoplasma Broth Base (Baltimore Biological Laboratory, Baltimore, Maryland, U.S.A.) supplemented with $10 \%$ fresh yeast extract, 500 units of penicillin $/ \mathrm{ml}$, and either $20 \%$ unheated horse serum (Tissue Culture Select serum, Baltimore Biological Laboratory) or I \% bovine serum fraction (Difco, catalog no. 044I). A solid medium was prepared from either of the two combinations by adding $0.75 \%$ Ionagar No. 2 (Oxoid).

Antisera. Hyperimmune rabbit antisera were prepared to the classified and unclassified Mycoplasma and Acholeplasma species or strains listed in Table 2. For the most part, antigen preparations were from concentrated, washed suspensions of mycoplasmas grown in $1 \%$ bovine serum fraction broth. Suspensions were mixed with an equal quantity of 
Table 2. Species and strains to which antisera were prepared

Antisera prepared against the mycoplasmas listed were used in growth inhibition and immunofluorescence tests against caprine mycoplasmas.

Species and strain

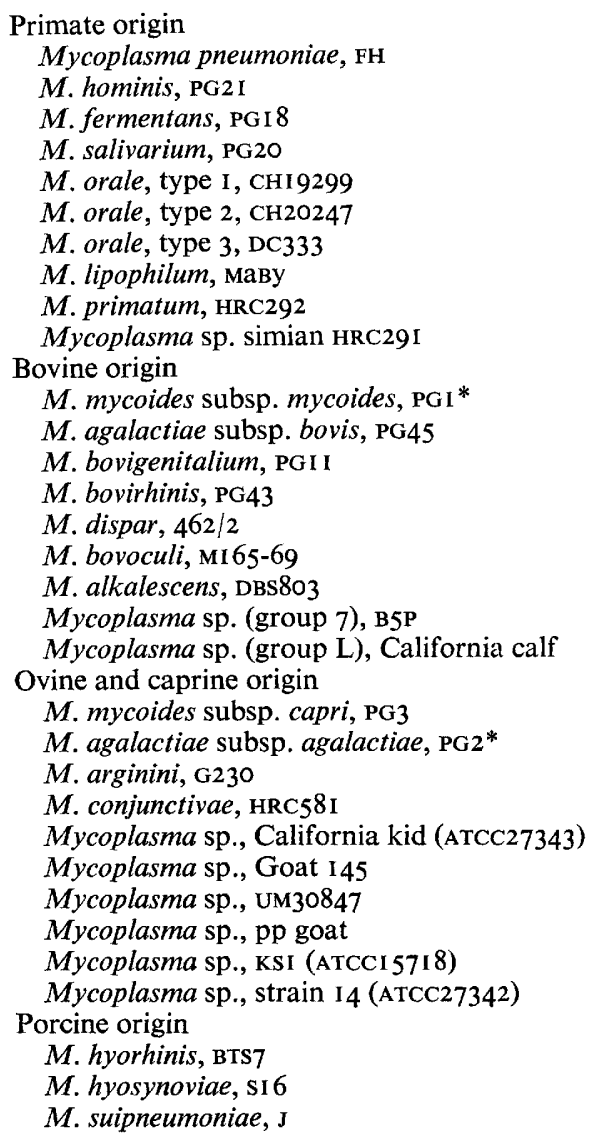

Species and strain

Rodent origin

$M$. neurolyticum, type A

M. pulmonis, PG34

M. arthritidis, $\mathrm{PG} 6$

M. caviae, GI 22

Canine origin

M. spumans, PGI 3

$M$. canis, PGI 4

M. maculosum, PGI 5

M. edwardii, $\mathrm{PG} 24$

$M$. cynos, MH4609

Mycoplasma sp. MH5408

Feline origin

M. felis, 27

$M$. gateae, Mart

M. feliminutum, Ben

Avian origin

M. gallisepticum, PG3I

M. gallinarum, $\mathrm{PGI} 6$

$M$. iners, $\mathrm{PG} 30$

$M$. anatis, $\mathrm{I} 340$

$M$. meleagridis, 17529

Mycoplasma sp. (group C), 859

Mycoplasma sp. (group D), 887

Mycoplasma sp. (group F), I 197

Mycoplasma sp. (group I), Iowa 695

Mycoplasma sp. (group L), 694

Acholeplasmas

Acholeplasma laidlawii, PG8

A. granularum, BTS39

A. axanthum, $\mathrm{s} 743$

A. modicum, PG49

A. oculusi, I9L

* Antisera not tested by plate immunofluorescence.

Freund's complete adjuvant and administered with a technique described by Al-Aubaidi \& Fabricant (I97I). Several strains in this study (B3, Uм30847, PG3) did not, as washed suspensions, induce satisfactory growth-inhibiting antibody. To obtain more potent antiserum to these strains, rabbits were first given an immunization series with washed antigens and adjuvant, followed by a series of bi-weekly intravenous inoculations $(0.5$ to $\mathrm{I} \cdot 0 \mathrm{ml})$ with unwashed, whole cell broth cultures grown $24 \mathrm{~h}$ in $\mathrm{I} \%$ bovine serum fraction medium. These inoculations were continued until the weekly trial bleedings showed the development of adequate growth-inhibiting antibody.

Serological tests. Disc growth-inhibition tests were by the method of Clyde (1964), using antigens prepared from $24 \mathrm{~h}$ cultures grown in serum fraction broth. Each antigen was diluted $I: 50, I: 100, I: 200$ and $I: 400$ in uninoculated serum fraction broth and the dilutions plated to serum fraction agar and then tested against undiluted antiserum. Metabolism inhibition (m.i.) tests were carried out with 'Microtiter' plates as described for fermenting 
mycoplasmas (Taylor-Robinson, Purcell, Wong \& Chanock, 1966), or for argininehydrolysing strains (Purcell, Taylor-Robinson, Wong \& Chanock, I966). Test antigens were prepared in the appropriate base medium and incubated at $37^{\circ} \mathrm{C}$ until a slight colour change in the indicator occurred. They were then distributed in vials $(3 \mathrm{ml}$ each) and frozen at $-70^{\circ} \mathrm{C}$. Just prior to m.i. tests, each vial of antigen was thawed, the concentration adjusted to approximately $10^{5}$ colony-forming units (c.f.u.)/ $/ \mathrm{ml}$, and the contents passed through a sterile $450 \mathrm{~nm}$ membrane filter. Lyophilized guinea-pig complement (Baltimore Biological Laboratory) was rehydrated in sterile, deionized water and added to the test medium to a final concentration of I0 \%. The complement-medium preparation was then filter-sterilized through a $450 \mathrm{~nm}$ membrane filter. All antisera used in the m.i. test were heated to $56{ }^{\circ} \mathrm{C}$ for $30 \mathrm{~min}$. Most m.i. tests were incubated at room temperature $\left(22\right.$ to $\left.25^{\circ} \mathrm{C}\right)$ and final readings recorded after 5 to 7 days. Metabolism inhibition tests on the Goat 145, G230, and HRC58I strains were done at $37^{\circ} \mathrm{C}$. The plate immunofluorescence antibody test was performed with the direct method (Del Giudice, Robillard \& Carski, 1967) utilizing mycoplasmas grown on serum fraction agar. The colonies were stained with appropriate dilutions (usually I :5 or I: Io) of fluorescein-conjugated antisera to most of the species listed in Table 2.

Biochemical tests. The procedures used to determine glucose, mannose and aesculin fermentation, arginine and urea hydrolysis, phosphatase production, tetrazolium reduction, serum digestion, and film and spots reaction have been described (Aluotto, Wittler, Williams \& Faber, 1970; Williams \& Wittler, 1971). Pigmented carotenoids were tested for by the technique of Razin \& Cleverdon (1965). Suceptibility of the mycoplasmas to digitonin was assayed by an agar plate method (Ernø \& Stipkovits, 1973; Freundt et al. 1973).

Tests for other biological properties. Haemolytic and haemadsorption activity of selected strains for ovine erythrocytes was determined as previously described (Manchee \& TaylorRobinson, 1968). The sterol requirement of representative strains was determined by a broth method (Razin \& Tully, 1970). The inoculum for each of these tests was prepared from organisms grown in serum fraction broth for $24 \mathrm{~h}$ at $37^{\circ} \mathrm{C}$.

Filtration characteristics. These were tested with representative strains grown for $24 \mathrm{~h}$ in serum fraction broth. Each culture was diluted I: Io in phosphate-buffered saline $\mathrm{pH} 7 \cdot 4$ containing $0.2 \%$ gelatin, and then filtered through a series of membrane filters with average pore diameters of 220, 300, 450 and $800 \mathrm{~nm}$. Swinney hypodermic adapters (Gelman, Ann Arbor, Michigan, U.S.A.) were employed with each filter and all were operated manually with minimal pressure. The number of c.f.u./ml was determined for the original I : Io dilution of the culture and for each representative filtrate by conventional plate counting procedures on serum fraction agar plates.

Polyacrylamide gel electrophoresis. The basic procedure employed has been described (Razin \& Rottem, 1967; Rottem \& Razin, 1967; Razin, 1968) but these techniques were modified to include a stacking gel (Theodore, King, Tully \& Cole, 1970). Briefly, mycoplasmas grown in serum fraction broth for 24 to $48 \mathrm{~h}$ were sedimented and the organism proteins solubilized in phenol-acetic acid-water ( $2 \mathrm{~g}: \mathrm{I} \mathrm{ml}: 0.5 \mathrm{ml}$ ). The extract was centrifuged and the clear supernatant was then added to an equal volume of $40 \%(\mathrm{v} / \mathrm{v})$ sucrose in $7 \%(\mathrm{v} / \mathrm{v})$ acetic acid. Approximately $0.1 \mathrm{ml}$ of the extract (200 to $300 \mu \mathrm{g}$ protein) was added to glass columns containing $\mathrm{I} \mathrm{ml}$ of separating gel $(7.5 \%$, w/v, acrylamide and $8 \mathrm{M}$ urea, $\mathrm{pH} 4.5)$ and $0.2 \mathrm{ml}$ of stacking gel $(2.5 \%$, w/v, acrylamide and $8 \mathrm{M}$-urea, $\mathrm{pH} 6 \cdot 7)$. The electrophoresis buffer was $0.07 \mathrm{M}-\beta$-alanine, adjusted to $\mathrm{pH} 4.5$ with acetic acid. Electrophoresis was carried out at a constant current of $4 \mathrm{~mA}$ per tube for $75 \mathrm{~min}$ at room temperature. Gels were stained for $60 \mathrm{~min}$ with $\mathrm{I} \%$ amido black in $7 \%(\mathrm{v} / \mathrm{v})$ acetic acid, rinsed in tap water, and de-stained by simple diffusion in $7 \cdot 5 \%$ (v/v) acetic acid. 


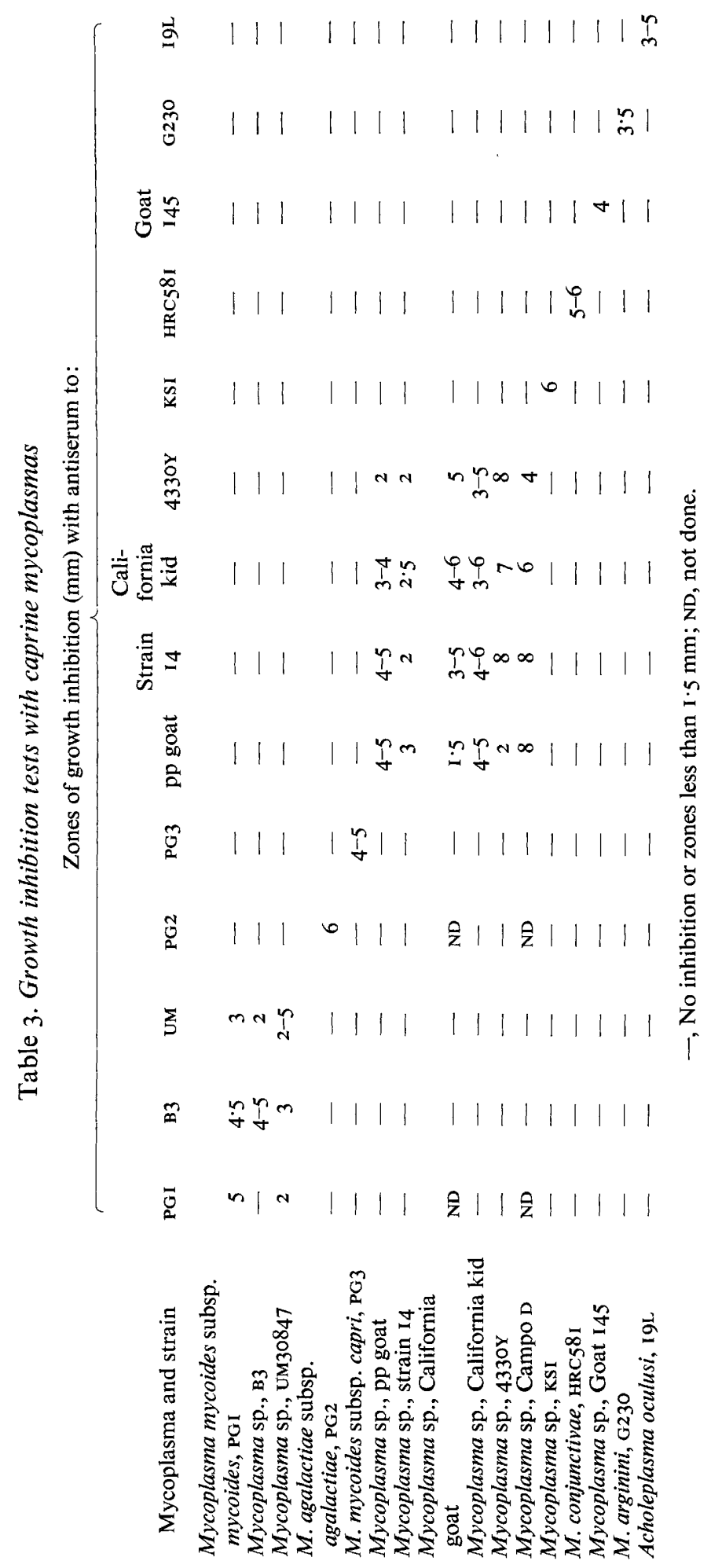


Electron microscopy. A two-day-old broth culture in serum fraction medium (40 ml) was centrifuged at $33000 \mathrm{~g}$ for $30 \mathrm{~min}$. The packed organisms were then washed twice in 5 to Io $\mathrm{ml}$ volumes of sodium-phosphate-buffered saline ( $\left.\mathrm{pH}_{7} \cdot 4\right)$. Subsequent electron microscopic techniques have been partially described (Popkin, Theodore \& Cole, I97I). The final pellets were resuspended in $2 \%(\mathrm{v} / \mathrm{v})$ glutaraldehyde buffered to $\mathrm{pH} 7.0$ in $0.2 \mathrm{M}$-sodium cacodylate and kept at room temperature for $5 \mathrm{~h}$. Centrifuged organisms were placed in $0.02 \mathrm{M}$-sucrose buffered at $\mathrm{pH} 7.0$ with $0 . \mathrm{I}$ M-phosphate and held $\mathrm{I} h$ at room temperature. Secondary fixation was in $\mathrm{I} \%(\mathrm{v} / \mathrm{v})$ osmium tetroxide in acetate-Veronal buffer overnight at room temperature. Fixed organisms were washed once in acetate-Veronal buffer and the pellets mixed with I drop of melted $2 \%(\mathrm{w} / \mathrm{v})$ Noble agar, dispensed on glass slides, and allowed to solidify. Agar cubes were prepared, washed overnight in $0.5 \%$ (v/v) uranyl acetate in acetate-Veronal buffer, and embedded in Epon 8I2. Thin sections were cut on an LKB Ultratome III with a diamond knife, placed on Formvar-coated copper grids, and stained for $3 \mathrm{~min}$ with alkaline lead citrate. Micrographs were recorded on Kodak Electron Image plates with a Hitachi HU-I I-C electron microscope operating at $75 \mathrm{kV}$.

\section{RESULTS}

\section{Serological characteristics of unclassified caprine mycoplasmas}

The initial effort was directed to a serological analysis of all of the various classified and unclassified mycoplasmas noted in Table $\mathrm{I}$. Results of the growth-inhibition test (Table 3 ) indicated that the B3 swine strain and UM30847 goat strain were closely related to each other and to the PGI strain of $M$. mycoides subsp. mycoides. None of the caprine or other strains appeared to be related to the $\mathrm{PG} 3$ strain of $M$. mycoides subsp. capri. Six of the remaining eight unclassified mycoplasmas, including the pp goat strain, showed sufficient serological cross-reactivity to indicate that they belong to a single group. The remaining two unclassified strains, Goat I45 and KSI, each appeared to be serologically distinct from most other caprine mycoplasmas by the growth-inhibition test. The results of the m.i. test (Tables 4,5 ) generally showed the distinctions and interrelationships seen with the growthinhibition procedure, although the Goat I45 strain exhibited a one-way cross-reaction with $M$. arginini.

All of the unclassified caprine mycoplasmas were also compared serologically with many other human and animal mycoplasmas. The comparisons were made largely with the growth-inhibition and plate fluorescent antibody tests utilizing specific antisera or fluorescein-conjugated antisera to the Mycoplasma and Acholeplasma species listed in Table 2. There was no evidence from these tests that any of the unclassified caprine or other strains, with the exceptions of the $\mathrm{B} 3$ and UM 30847 strains, were related to established species within the Mycoplasmatales.

Electrophoretic patterns. The protein patterns of the B3 and UM30847 strains were similar (Fig. I) and the results appeared to support the serological relationships noted above. Although the lower portion of the protein pattern of the PG3 strain of $M$. mycoides subsp. capri was similar to that of the B3 and UM30847 strains, there were obvious differences in the upper portion (Fig. I). An analysis of the patterns obtained with the six unclassified, but serologically related, caprine mycoplasmas indicated close agreement in the number and spacing of their protein bands. The KSI strain presented a protein pattern distinct from all other caprine mycoplasmas examined here (Fig. 2). 


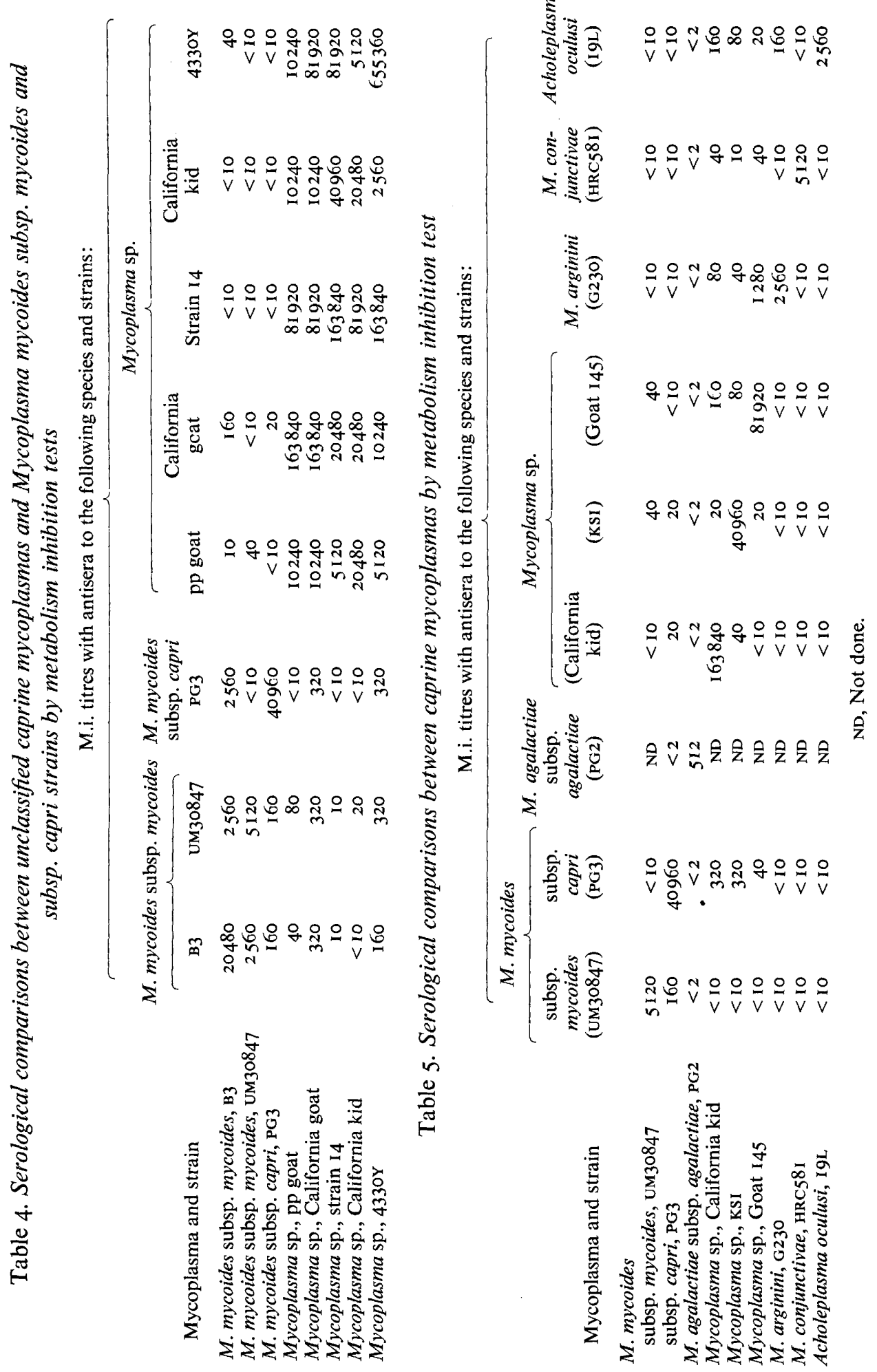




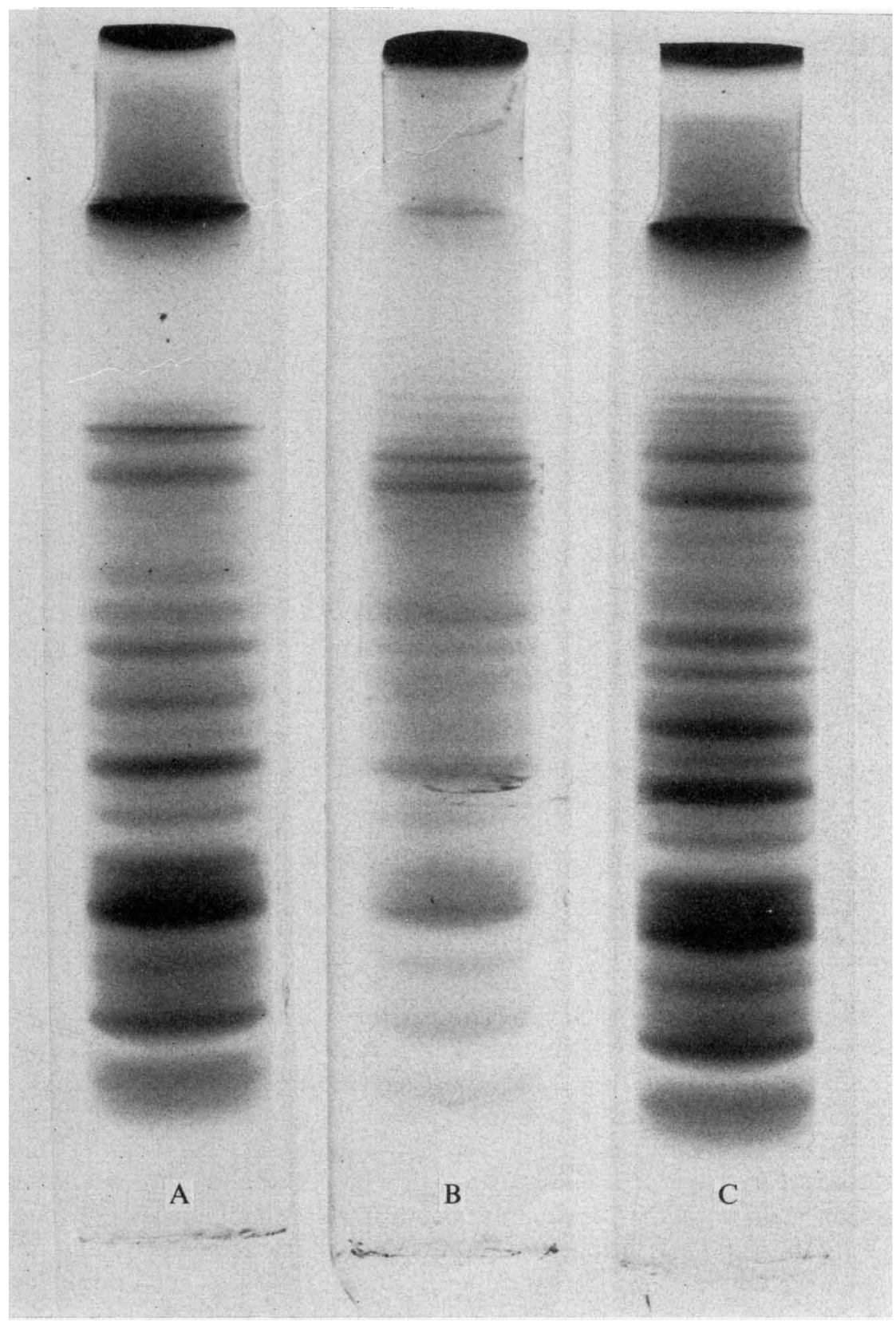

Fig. I. Electrophoretic patterns of mycoplasma proteins; $(a)$ в3 strain, (b) UM30847 strain, (c) PG3 strain.

General characteristics of the California kid group

The California kid (ATCC27343) strain was selected as representative of the unclassified caprine mycoplasmas in this group and this strain was examined in biochemical and biological tests to establish its relevant classification within the Mycoplasmatales (Subcommittee on Taxonomy of the Mycoplasmatales, I972); other members of this group were included to assess variations in strain characteristics. 


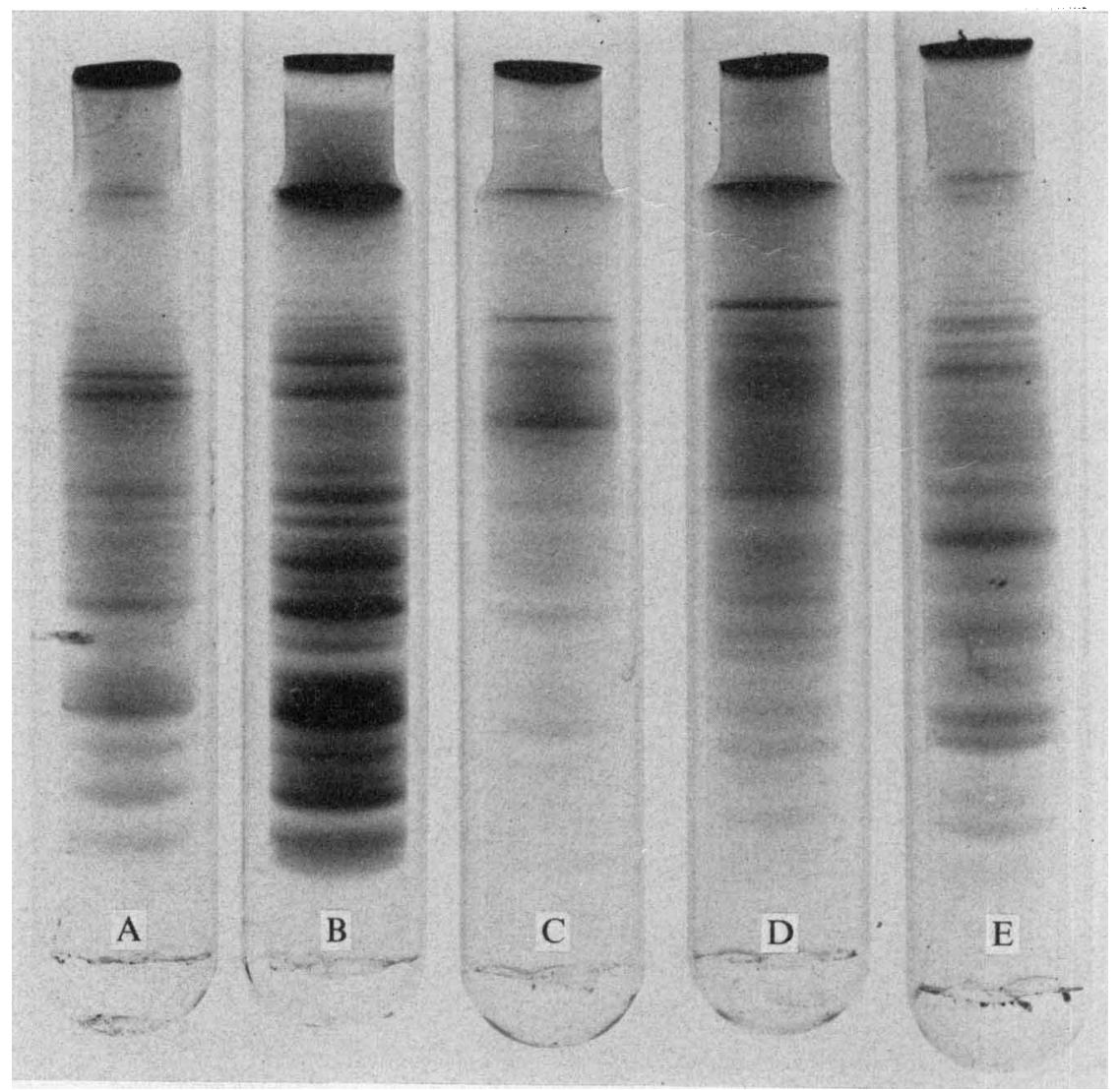

Fig. 2. Electrophoretic patterns of the proteins of representative caprine mycoplasmas. (a) $M y c o-$ plasma mycoides subsp. mycoides, UM30847; (b) M. mycoides subsp. capri, $\mathrm{PG} 3 ;(c) M$. capricolum, California kid.

Morphology and colonial appearance. An examination of the cellular morphology by phase contrast microscopy revealed that these strains consisted of a mixture of small, pleomorphic cocco-bacillary forms and some very short filamentous elements. All were Gram-negative. Electron microscopic observations on thin-section preparations showed various round or irregular cells, 200 to $1000 \mathrm{~nm}$ in diameter, and a few short filaments (Fig. 3). Most of the larger irregularly shaped cells possessed a uniform internal density of ribosome-like particles. All of the strains examined by electron microscopy (California kid, strain 14 , and pp goat) exhibited similar morphological characteristics and were bounded only by a typical unit or triple-layer membrane. Strains grown on solid medium produced the usual 'fried egg' colony. All strains in the group were carried through 15 passages in liquid medium containing no penicillin or other bacterial inhibitors. There was no evidence of reversion to bacterial forms when these cultures were examined by Gram stain procedure or plated to an antibiotic-free solid medium.

Filtration characteristics. Undiluted broth cultures of the California kid strain contained $2.34 \times 10^{11}$ c.f.u. $/ \mathrm{ml}$, and the filtrates yielded $2.5 \times 10^{10}, 1.95 \times 10^{8}, 9.5 \times 10^{7}$ and $2.43 \times 10^{5}$ c.f.u. $/ \mathrm{ml}$ for the $800,450,300$ and $200 \mathrm{~nm}$ filters, respectively. The pp goat and strain I 4 cultures showed similar filtration patterns.

Sterol requirement. All strains in the group required serum or cholesterol for growth. The 


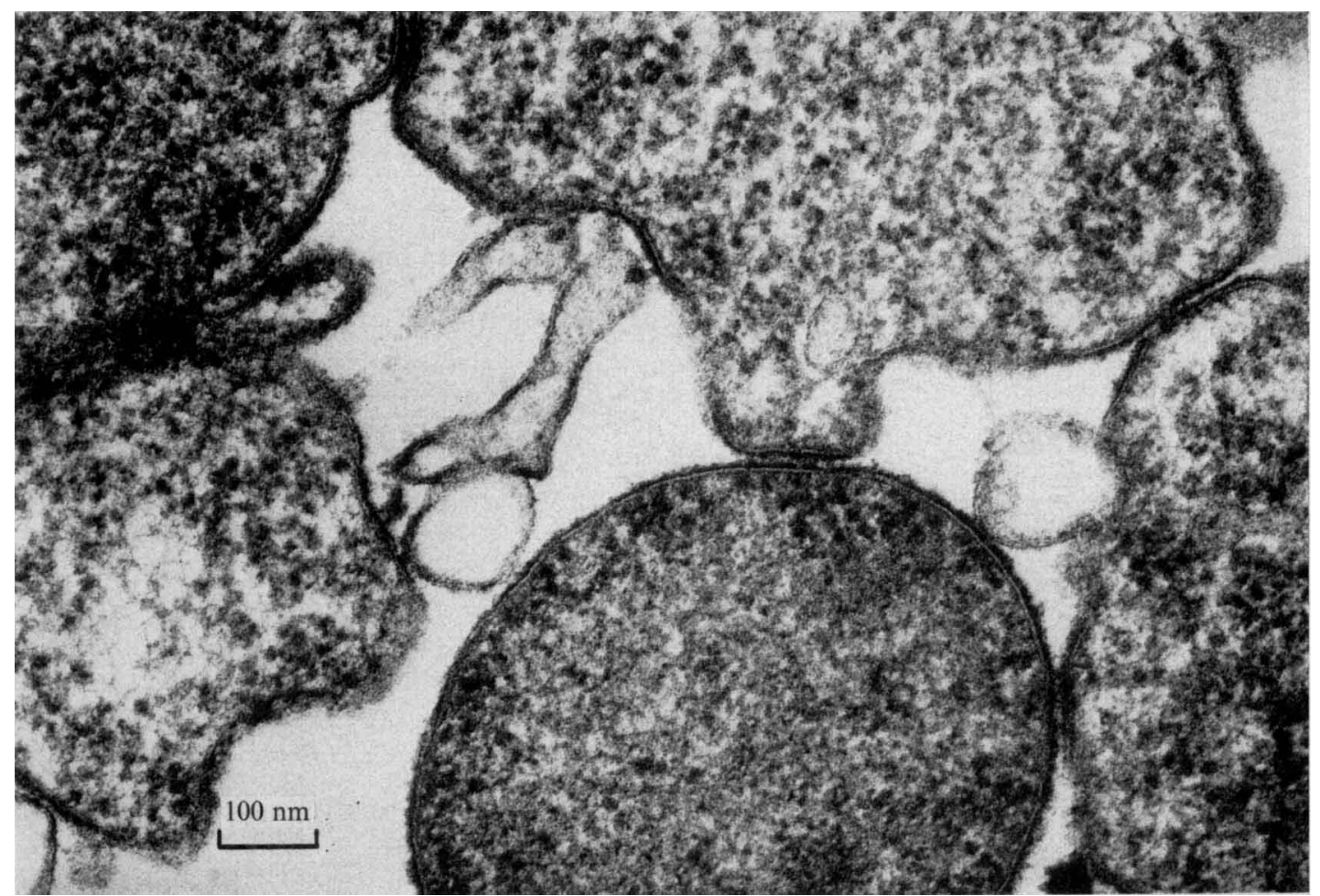

Fig. 3. Electron micrograph of thin-section preparation of California kid (ATCC27343) showing irregular cell shapes, few short filaments, and unit membrane.

specific response of the California kid strain to various quantities of cholesterol is presented in Table 6. Although the addition of a fatty acid (Tween 80 ) to serum-free medium did provide some enhanced growth, cholesterol supplements ( 5 to $10 \mu \mathrm{g} / \mathrm{ml}$ ) gave larger growth yields. The pp goat, California goat, strain 14 , and 4330 y mycoplasmas gave similar growth responses to cholesterol.

Biochemical and biological properties. These are summarized for the six unclassified mycoplasmas, together with data for other recognized caprine mycoplasmas (Table 7). All six strains fermented glucose and mannose and four strains also hydrolysed arginine. Four of the mycoplasmas in this group liquefied coagulated serum, as did two of three $M$. mycoides subsp. mycoides strains. Digitonin inhibited the growth of all mycoplasmas except the I9L strain of Acholeplasma oculusi.

The California kid strain was also subjected to a more extensive series of biological tests (Table 8); other strains in the group gave similar results.

\section{General characteristics of the KSI strain}

Morphology and colonial appearance. The cellular morphology of the KSI strain was generally similar to that of the California kid group. Phase-contrast and electron microscopic observations revealed predominantly coccoid forms with only a few filaments (Fig. $4 a, b)$. There was no evidence of wall components and all cells contained only the unit membrane. Stained preparations were Gram-negative and no reversion to bacterial forms occurred during 15 passages in antibiotic-free medium. Broth cultures exhibited a rather 
Table 6. Effect of cholesterol on the growth of representative caprine mycoplasmas

The growth response to cholesterol was assessed as mycoplasma protein (Razin \& Tully, 1970). Control samples contained $\mathrm{I} \%$ serum-fraction in medium.

$\begin{array}{ccc}\text { Cholesterol in medium } \\ (\mu \mathrm{g} / \mathrm{ml}) & \begin{array}{c}\text { California kid } \\ \text { (ATCC27343) }\end{array} & \begin{array}{c}\text { Mycoplasma protein } \\ (\mathrm{mg} / \mathrm{I00} \text { ml medium) }\end{array} \\ \text { O* }_{\text {(ATCC15718) }} & 0.01 \\ \text { of } & 0.06 & 0.06 \\ \text { of } & 0.38 & 0.03 \\ 1.0 & 2.25 & 2.45 \\ 5.0 & 3.75 & 0.25 \\ 10.0 & 10.00 & 0.26 \\ 20.0 & 10.90 & 0.13 \\ \text { Control } & 9.30 & 6.73\end{array}$

* Serum-free medium alone.

$\uparrow$ Serum-free medium with $0.5 \%$ albumin and Io $\mu \mathrm{g}$ palmitic acid $/ \mathrm{ml}$.

\$ Serum-free medium with $0.5 \%$ albumin, $10 \mu \mathrm{g}$ palmitic acid $/ \mathrm{ml}$ and $0.01 \%$ Tween 80 .

Table 7. Biochemical characteristics of some caprine mycoplasmas

\begin{tabular}{|c|c|c|c|c|c|c|}
\hline \multirow[b]{2}{*}{ Mycoplasma } & \multirow[b]{2}{*}{ Strain } & \multicolumn{3}{|c|}{ Utilization of } & \multirow{2}{*}{$\begin{array}{l}\text { Liquefac- } \\
\text { tion of } \\
\text { coagulated } \\
\text { serum }\end{array}$} & \multirow{2}{*}{$\begin{array}{c}\text { Sensitivity } \\
\text { to } \\
\text { digitonin* }\end{array}$} \\
\hline & & Glucose & Mannose & Arginine & & \\
\hline M. mycoides subsp. mycoides & PGI & + & + & - & - & 9 \\
\hline M. mycoides subsp. mycoides & B3 & + & + & - & + & 7 \\
\hline $\begin{array}{l}\text { M. mycoides subsp. mycoides } \\
M . \text { agalactiae subsp. }\end{array}$ & UM30847 & + & + & - & + & 6 \\
\hline agalactiae & $\mathrm{PG} 2$ & - & - & - & - & 7 \\
\hline M. mycoides susp. capri & PG3 & + & + & - & + & 7 \\
\hline Mycoplasma sp. & pp goat & + & + & + & + & 7 \\
\hline Mycoplasma sp. & California goat & + & + & + & + & 8 \\
\hline Mycoplasma sp. & California kid & + & + & + & + & 8 \\
\hline Mycoplasma sp. & $4330 Y$ & + & + & - & + & I 2 \\
\hline Mycoplasma sp. & Campo D & + & + & $\mathrm{V} \dagger$ & - & 13 \\
\hline Mycoplasma sp. & Strain I4 & + & + & $\mathrm{Vt}$ & - & 8 \\
\hline Mycoplasma sp. & KSI & + & + & - & - & 9 \\
\hline Mycoplasma sp. & Goat 145 & - & - & + & - & I4 \\
\hline$M$. arginini & G230 & - & - & + & - & 10 \\
\hline M. conjunctivae & HRC 58I & + & + & - & - & I I \\
\hline Acholeplasma oculusi & I9L & + & + & - & - & 0 \\
\hline
\end{tabular}

* Zones of inhibition (mm) around discs saturated with $\mathrm{x} \cdot 5 \%$ digitonin.

$\uparrow$ Results variable but positive tests recorded.

uniform heavy turbidity after $24 \mathrm{~h}$, with a strong putrid odour. Agar plates inoculated with a diluted broth culture of the KSI strain showed typical 'fried egg' colonies. The odour associated with broth cultures was also noted with growth on a solid medium.

Filtration characteristics. An undiluted broth culture of the KSI strain contained $8 \cdot 3 \times 10^{7}$ c.f.u./ml, and filtrates yielded $6 \cdot 56 \times 10^{7}, \mathrm{I} \cdot 0 \times 10^{7}, 8 \cdot 2 \times 10^{6}$ and $4 \cdot 16 \times 10^{5}$ c.f.u. $/ \mathrm{ml}$ for the $800,450,300$ and 200 filters, respectively.

Sterol requirement. The growth of the KSI strain could not be maintained in a medium devoid of serum. Cholesterol requirement tests indicated a narrow concentration range 
Table 8. Biological characteristics of mycoplasmas typified by California kid and KSI strains

\begin{tabular}{|c|c|c|}
\hline & $\begin{array}{l}\text { California kid } \\
\text { (ATCC27343) }\end{array}$ & $\begin{array}{c}\text { KSI } \\
(\text { ATCCI } 57 \text { I } 8)\end{array}$ \\
\hline Fermentation of glucose and mannose & + (acid) & + (acid) \\
\hline Fermentation of aesculin & - & - \\
\hline Hydrolysis of arginine & + (variable) & - \\
\hline Hydrolysis of urea & - & - \\
\hline Haemolysis (ovine RBC) & Beta & Alpha \\
\hline Haemadsorption (ovine RBC) & - & + \\
\hline Phosphatase & + & + \\
\hline Tetrazolium reduction (aerobic/anaerobic) & $+1+$ & $+1+$ \\
\hline Liquefaction of coagulated serum & + & - \\
\hline Film and spots & - & - \\
\hline Carotenoid production & - & - \\
\hline Sterol requirement & + & + \\
\hline Culture turbidity & Light to heavy & Heavy (putrid odour) \\
\hline Colonies on agar & \multicolumn{2}{|c|}{ Large colonies with 'fried egg' appearance } \\
\hline Preferred atmosphere & Aerobic & Aerobic \\
\hline Cellular morphology & \multicolumn{2}{|c|}{$\begin{array}{l}\text { Gram-negative, pleomorphic coccoid } \\
\text { elements and short filaments }\end{array}$} \\
\hline $\begin{array}{l}\text { Guanine and cytosine content of DNA } \\
(\mathrm{mol} \%)\end{array}$ & $\begin{array}{c}25.5 \\
\text { (Neimark \& Pene, I 965) }\end{array}$ & $\begin{array}{l}28 \cdot 9 \\
\text { (Williams et al. 1969) }\end{array}$ \\
\hline Protein electrophoretic patterns & \multirow{2}{*}{\multicolumn{2}{|c|}{$\begin{array}{l}\text { Distinct from other Mycoplasma and } \\
\text { Acholeplasma species } \\
\text { Serologically distinct from other } \\
\text { Mycoplasma and Acholeplasma species }\end{array}$}} \\
\hline Antigenicity & & \\
\hline \multicolumn{3}{|l|}{ Pathogenicity for goats (Barber \& } \\
\hline Yedloutschnig, I970) & + & - \\
\hline Habitat and source & Goat & Uncertain \\
\hline
\end{tabular}

(approx. I $\mu \mathrm{g} / \mathrm{ml}$ ) for optimally enhanced growth in liquid medium (Table 6). Larger amounts of cholesterol ( 5 to $20 \mu \mathrm{g} / \mathrm{ml}$ ) appeared to be inhibitory.

Biochemical and biological properties. The KSI strain possesses the general biochemical activities of other caprine mycoplasmas (Tables 7,8 ). It ferments glucose and mannose rapidly but does not hydrolyse arginine or liquefy clotted serum broth. It is unique among mycoplasmas in having a strong putrid odour.

\section{DISCUSSION}

The first group of mycoplasmas considered in this study is represented by six strains [pp goat, California goat, strain I4, California kid (ATCC27343), 4330Y, and Campo D]; there is evidence that several of these strains had a common origin. The pp goat isolate was obtained from the Mycoplasma Reference Laboratory (Colindale). It apparently represents a subline of the original Chu and Beveridge mycoplasma recovered from a Turkish goat with contagious pleuropneumonia (Cottew \& Leach, 1969). It was sent to Klieneberger at the Lister Institute (Lemcke, 1964) from where it was transferred to the Reference Laboratory. The Chu and Beveridge strain was also sent directly to Edward, then at the Wellcome Laboratories, who then studied this strain (Edward, 1953) and later (Edward, I954; Edward \& Freundt, 1956) proposed it as the type culture (PG3) of $M$. mycoides subsp. capri. It has since been assumed by many investigators that the pp goat and PG3 strains were identical. Our results show that pp goat is biochemically and serologically distinct from the PG3 strain. At the completion of our study, we learned that Lemcke (1974) had reached the same conclusion. 

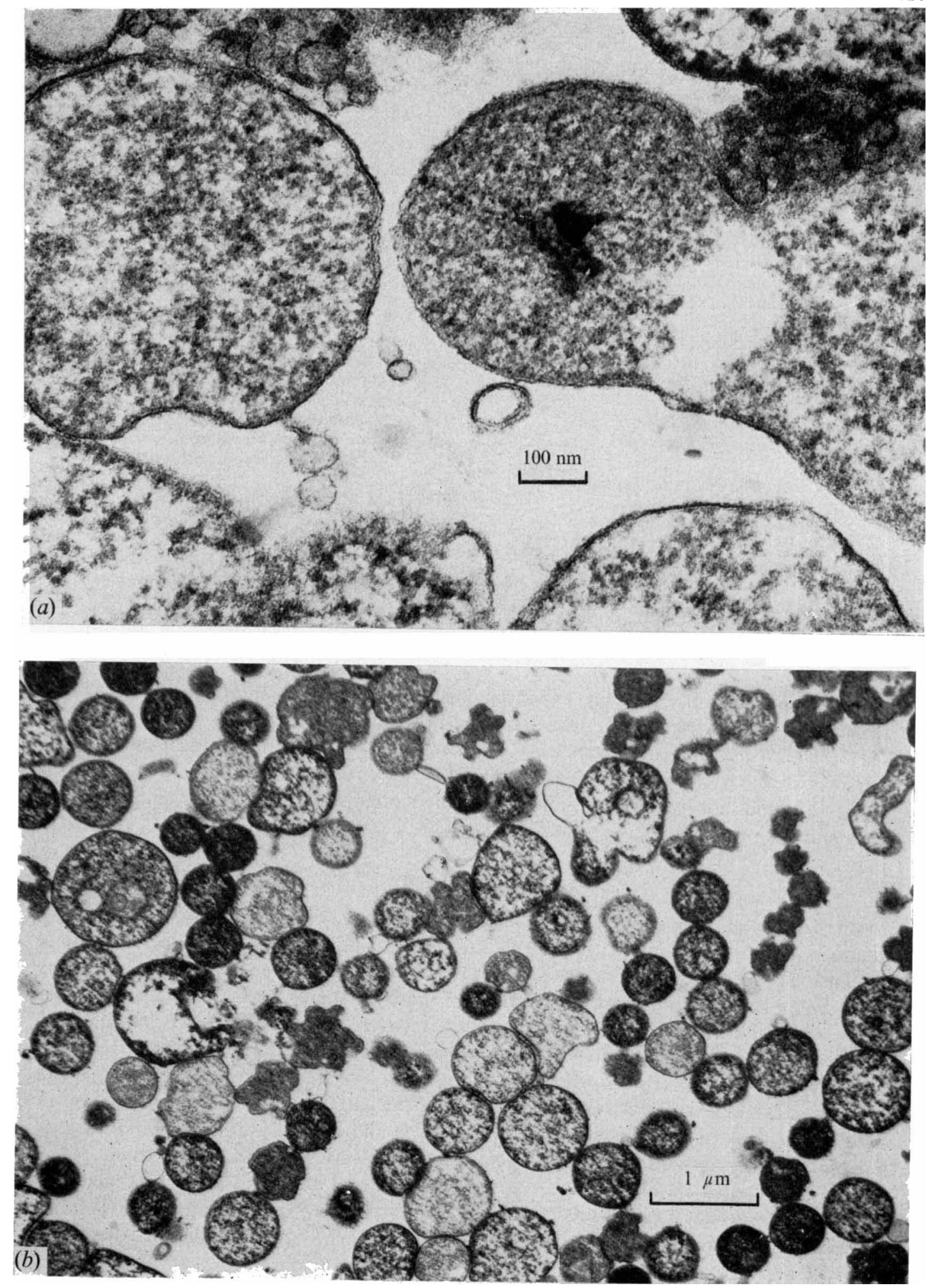

Fig. 4. Electron micrographs of thin-section preparations of XSI (ATCCI 57I 8). (a) High magnification showing unit membrane. (b) Lower magnification showing general uniform size of round cell population and very few filamentous forms. 
The status of the California goat strain is also complicated, not only by several changes in strain designation after the culture was transferred to other investigators and the obviously uncertain ancestry of these sublines, but also by some similarity in the pathogenicity of this strain and classical caprine pleuropneumonia mycoplasmas. The original isolation of the California goat organism was made from the swollen leg joint of a young goat involved in a natural outbreak in a commercial goat herd (Cordy, Adler \& Yamamoto, 1955). The disease, which was fatal to all kids infected with the agent, was characterized by septicaemia, acute polyarthritis, and occasionally conjunctivitis in older goats. Experimental reproduction of the disease was confirmed in kids and the organism was pathogenic for sheep and pigs (Cordy \& Adler, 1960). Although mycoplasmas recovered from the young goats resembled the agent of caprine pleuropneumonia in growth characteristics and biochemical activities, none of the animals in the field cases exhibited pneumonia, nor was this clinical manifestation observed in the experimental disease (Cordy \& Adler, 1960). The clear distinction of this disease from classical caprine pleuropneumonia was noted by Hudson, Cottew \& Adler (I967) and their investigations, as well as that of Cottew \& Lloyd (I965), showed that the California goat organism was serologically distinct from $M$. mycoides subsp. mycoides (v5) and several other caprine mycoplasmas, although it was never compared directly with the type strain, $\mathrm{PG}_{3}$, of $M$. mycoides subsp. capri. The California goat strain has also been subjected to a variety of other tests since its original isolation, including its biochemical (Neimark \& Pickett, 1960) and genetic (Neimark, I967; Ryan \& Morowitz, I969) properties. Jonas \& Barber (I969) carried out a biochemical and serological comparison of this strain and other caprine mycoplasmas and concluded that it differed in many respects from mycoplasmas associated with caprine pleuropneumonia. Finally, Barber \& Yedloutschnig (1970) examined the pathogenicity of a lyophilized culture of this strain, prepared in 1958 , and found that it produced a disease in goats very similar to that obtained with some mycoplasmas (Vom, Connecticut, Mexican and 29 I 2 strains) which were thought, at the time, to be representative of $M$. mycoides subsp. capri. Since no serological data were offered in the pathogenicity study to show the relationship of these four strains to $M$. mycoides subsp. capri, the inference that the California goat organism was involved in caprine pleuropneumonia or was related to strains of $M$. mycoides subsp. capri is questionable. More recent data (Perreau, I97I; Al-Aubaidi, Dardiri \& Fabricant, 1972) indicate that the Vom strain and other mycoplasmas used in the pathogenicity study are more closely related to $M$. mycoides subsp. mycoides. We utilized three sublines of the original California caprine mycoplasma: California goat, received from H. C. Neimark (Neimark, 1967), who had acquired it directly from H. E. Adler; California kid (ATCC27343), placed in the American Type Culture Collection by H. J. Morowitz; and strain I4 (ATCC27342), placed in the ATCC by M. E. Tourtellotte (Tourtellotte \& Jacobs, 1960).

Two additional mycoplasmas, of questionable origin, were also found to belong to this group of caprine mycoplasmas. The original 4330 culture was supposedly isolated from a human uterine cervix by L. Dienes around 1940 (Morton \& Roberts, 1967). Morton \& Roberts ( 1967 ) examined what were thought to represent several sublines of the original culture, some of which were mixed with Acholeplasma laidlawii. However, a purified culture, designated 4330Y (ATCC23205) was obtained and identified in their tests as being serologically related to $M$. hominis. This culture was examined by R. H. Purcell (personal communication), who was unable to confirm its relationship to $M$. hominis. He did observe that the organism showed a significant cross-reaction in complement-fixation tests against antiserum to a caprine mycoplasma ( $p$ p goat). The 4330 Y (ATCC23205) culture was used in the current study. The Campo D strain was apparently isolated by Dienes from the urethra 
of a male patient at about the time the 4330 cuiture was obtained (Morton, 1970). Serological tests carried out by Dienes (Morton \& Robarts, 1967; Morton, 1970) indicated that the Campo D and 4330 strains were related. It should be noted that the Campo D strain we employed (obtained from J. T. Sharp) is not related serologically to the Campo strain that was subsequently shown to be identical to $M$. arthritidis strains (Lemcke, 1964; Edward \& Freundt, 1965; Tully, 1965). Whether either of the 4330 Y or Campo D mycoplasmas available now actually represents the original cultures or was, indeed, isolated from man is now open to question. The most likely explanation is that since the California goat strain was present in the laboratory where both the 4330 and Campo D strains originated (J. T. Sharp, personal communication), an interchange might have occurred.

The six mycoplasmas in this group were clearly distinct from other caprine and animal mycoplasmas and there was no evidence from growth-inhibition, metabolic-inhibition, or fluorescent antibody tests that they shared any relationship to the type culture, PG3, of $M$. mycoides subsp. capri. Most of the mycoplasmas in the group possessed very similar biological and biochemical properties. The guanine and cytosine $(\mathrm{G}+\mathrm{C})$ composition of the DNA of the various strains in this group (Neimark \& Pene, 1965; Neimark, 1967; Kelton \& Mandel, 1969; Neimark, 1970) also indicates a close relationship. It is therefore proposed that this group of six strains be classified within the Mycoplasmatales and designated Mycoplasma capricolum (L. m. genitive, capri, of a goat; L. v. incolere, to dwell; L. part. adj. n., capricolum, goat-dwelling). The California kid strain (ATCC27343) is designated the type strain of $M$. capricolum.

The KSI strain, isolated initially in 1954 by H. E. Adler, was supposedly derived from the same goats infected with the California goat strain. The KSI strain was deposited in the ATCC in 1964 (ATCCI5718). However, subsequent investigations on the biological and genetic properties of this strain raised doubts about its similarity to the original California goat strain and even whether it actually had come from a goat (R. G. Wittler, personal communication). The DNA base ratio composition of KSI was $28.9 \%$ (Williams, Wittler \& Burris, I969) and that of the California goat strain $25.5 \%$ (Neimark \& Pene, I965). The KSI culture also failed to liquefy coagulated serum or haemolyse ovine erythrocytes, properties observed earlier with the original California goat isolate (R. G. Wittler, personal communication). Additional investigations comparing the two strains (Jonas \& Barber, I969; Barber \& Yedloutschnig, 1970) showed that the KSI strain (referred to in their studies as the 1967 strain) was not pathogenic for goats and differed in several respects from the biochemical and serological properties of the original California goat strain. Our results (Table 8) confirm the distinctions made earlier between these two cultures, and our more extensive serological comparisons with the KSI and other caprine and animal mycoplasmas show it to be distinct from known Mycoplasma and Acholeplasma species. The requirement for cholesterol by the KSI strain would place it within the family Mycoplasmataceae. We propose that this strain be classified as a new species, designated Mycoplasma putrefaciens sp.nov. (L. v. putrefacere, to make rotten; L. part. adj. putrefaciens, making rotten or putrefying). The specific epithet connotes the production of a putrid odour in broth and agar cultures. The KSI strain (ATCCI 57I8) is the type culture by monotypy.

The present study would therefore expand the list of classified caprine mycoplasmas to seven distinct species or subspecies within the order Mycoplasmatales. Since many of these have been recovered from sheep and a few are also capable of producing disease in both hosts (Cottew \& Leach, 1969), it has been customary to group together caprine and ovine mycoplasmas in lists relating to specific host flora. The current list of classified caprine and ovine mycoplasmas (Table 9) does not include several unclassified, but apparently distinct, 
Table 9. Mycoplasmatales of sheep and goats

\begin{tabular}{|c|c|c|c|c|}
\hline \multirow[b]{2}{*}{ Species } & \multirow[b]{2}{*}{ Type strain } & \multicolumn{2}{|c|}{ Host } & \multirow[b]{2}{*}{ Recovery site } \\
\hline & & Sheep & Goat & \\
\hline M. agalactiae subsp. agalactiae & PG2 & + & + & Eye, joint, blood, genito urinary tract \\
\hline M. mycoides subsp. mycoides & PGI & + & + & Respiratory tract \\
\hline M. mycoides subsp. capri & PG3 & - & + & Respiratory tract \\
\hline M. arginini & G230 & + & + & Eye, joint, respiratory tract \\
\hline$M$. conjunctivae & HRC58I & + & + & Eye \\
\hline A. oculusi & I9L & - & + & Eye \\
\hline M. capricolum sp.nov. & California kid & - & + & Joint, blood, eye \\
\hline M. putrefaciens sp.nov. & KSI & - & $?$ & Joint? \\
\hline
\end{tabular}

mycoplasmas that have been recovered from these hosts. A recent study of I 3 I ovine and goat mycoplasmas (J. M. Al-Aubaidi, personal communication) established at least I2 serologically distinct groups. Seven of these groups are represented by the classified species listed in Table 9. Al-Aubaidi considered the Goat 145 strain, one of the remaining unclassified caprine mycoplasmas, to be distinct from other caprine mycoplasmas. These observations are in agreement with previous investigations (R. A. Del Giudice, personal communication) and with most of the data presented here. Further information on the antigenic and biological properties of Goat 145 may help to establish the eventual taxonomic status of this organism. Another member of the unclassified group of caprine mycoplasmas has been described recently as a new species, $M$. ovipneumoniae (Carmichael, St George, Sullivan \& Horsfall, 1972). This organism is apparently an important agent in proliferative interstitial pneumonia of sheep (Sullivan, St George \& Horsfall, 1973). Although various strains (Y98 and related organisms) of $M$. ovipneumoniae seem to be distinct from other caprine and ovine mycoplasmas, the taxonomic description did not include a comparison of these strains to other mycoplasmas of human and animal origin, nor did the authors indicate a type species.

Our identification of the UM30847 (goat) and B3 (swine) strains as $M$. mycoides subsp. mycoides adds further information to the host distribution of this organism. Although its host range under natural conditions has generally been thought to be limited to cattle, recent evidence indicates that $M$. mycoides subsp. mycoides is capable of producing disease in both sheep and goats (Laws, 1956; Hudson et al. 1967; Cottew, Watson, Erdag \& Arisoy, 1969; Barber \& Yedloutschnig, I970; Al-Aubaidi et al. 1972; Ernø, Freundt, KrogsgaardJensen \& Rosendal, 1972). The occurrence of this Mycoplasma species in swine has not been noted previously and it is uncertain whether the B3 isolate recovered from swine (Dinter, Danielsson \& Bakos, I965) represents a further extension of the host range or whether the pig merely acts as a passive host for these mycoplasmas.

One of the major problems in clarifying the role of various mycoplasmas, and especially of the two M. mycoides subspecies, in caprine infections has been the general lack of agreement among investigators as to the appropriate reference strain for diagnostic serological procedures. The use of caprine mycoplasmas other than the PG3 type culture of $M$. mycoides subsp. capri to identify related mycoplasmas gave the false impression that this organism is present in caprine populations in certain geographic areas. This is particularly obvious with serological tests based upon either the Vom strain, now identified as $M$. mycoides subsp. mycoides (Perreau, I97I), or the pp goat strain, identified here as $M$. capricolum sp.nov. There is little evidence that $M$. mycoides subsp. capri, or mycoplasmas related to the PG3 strain, are present in the U.S.A., contrary to what has been reported (Jonas \& Barber, I969; Barber \& Yedloutschnig, I970; Yedloutschnig, Taylor \& Dardiri, 1971 ; Pearson et al. 1972). 
In all of these reports where specific serological data is available, the identification of so-called $M$. mycoides subsp. capri strains is based upon comparison of isolates to mycoplasmas that have now been shown to be identical with $M$. mycoides subsp. mycoides (Al-Aubaidi et al. 1972). Although it would appear that $M$. mycoides subsp. mycoides is involved in some very isolated and localized caprine infections in the U.S.A., no evidence exists to incriminate this organism in natural bovine infections in that country. As noted recently (Al-Aubaidi et al. 1972), the PG3 strain represents a satisfactory reference culture for caprine pleuropneumonia strains and is the valid type culture of $M$. mycoides subsp. capri. There is also sufficient information (Al-Aubaidi et al. 1972) to indicate that the PGI strain fulfils the same requirements and is representative of $M$. mycoides subsp. mycoides. Although each of these reference strains is no longer virulent for its respective primary host (El Nasri, 1967; see also Lloyd, 1970; Edward \& Freundt, 1973), they should be employed in all serological tests to identify unknown mycoplasmas recovered from all appropriate natural hosts.

We thank G. S. Cottew, E. A. Freundt and H. C. Neimark for reviewing the manuscript and offering valuable suggestions on the contents. We are also indebted to R. M. Cole and T. J. Popkin for their efforts in the preparation, examination, and photography of specimens for electron microscopy. Special thanks are due to N. G. Ramsburg, C. Blood, J. Nolke, and M. W. Grabowski for their technical assistance.

\section{REFERENCES}

Al-Aubaidi, J. M., Dardiri, A. H. \& Fabricant, J. (1972). Biochemical characterization and antigenic relationship of Mycoplasma mycoides subsp. mycoides Freundt and Mycoplasma mycoides subsp. capri Freundt. International Journal of Systematic Bacteriology 22, I 55-164.

Al-Aưbidi, J. M., Dardiri, A. H., Muscoplatt, C. C. \& McCauley, E. H. (1973). Identification and characterization of Acholeplasma oculusi sp.nov. from the eyes of goats with keratoconjunctivitis. Cornell Veterinarian 63, I I 7-1 29.

Al-Aubaidi, J. M. \& FabricANT, J. (1971). Characterization and classification of bovine mycoplasma. Cornell Veterinarian 6r, 490-518.

Aluotto, B. B., Wittler, R. G., Williams, C. O. \& Faber, J. E. (I970). Standardized bacteriologic techniques for the characterization of Mycoplasma species. International Journal of Systematic Bacteriology $20,35-58$.

Barber, T. L. \& Yedloutschnig, R. J. (1970). Mycoplasma infections of goats. Cornell Veterinarian 60, 297-308.

Barile, M. F., Del Giudice, R. A., Carski, T. R., Gibbs, C. J. \& Morris, J. A. (I968). Isolation and characterization of Mycoplasma arginini sp.nov. Proceedings of the Society for Experimental Biology and Medicine 129, 489-494.

Barile, M. F., Del Giudice, R. A. \& Tully, J. G. (1972). Isolation and characterization of Mycoplasma conjunctivae sp.nov. from sheep and goats with keratoconjunctivitis. Infection and Immunity 5, 70-76.

Carmichael, L. E., St George, T. D., Sullivan, N. D. \& Horsfall, N. (I972). Isolation, propagation, and characterization studies of an ovine Mycoplasma responsible for proliferative interstitial pneumonia. Cornell Veterinarian 62, 654-679.

Clyde, W. A., JUN. (1964). Mycoplasma species identification based upon growth inhibition by specific antisera. Journal of Immunology 92, 958-965.

CORDY, D. R. \& AdLER, H. E. (1960). Patterns of reaction in infection with a virulent form of PPLO from goats. Annals of the New York Academy of Sciences 79, 686-695.

Cordy, D. R., Adler, H. E. \& Yamamoto, R. (I955). A pathogenic pleuropneumonia-like organism from goats. Cornell Veterinarian 45, 50-68.

CotTew, G. S. \& LEACH, R. H. (1969). Mycoplasmas of cattle, sheep, and goats. In The Mycoplasmatales and the L-phase of Bacteria, chapter 19. Edited by L. Hayflick. New York: Appleton-Century-Crofts.

CotTEw, G. S. \& LloYd, L. C. (1965). An outbreak of pleurisy and pneumonia in goats in Australia attributed to a Mycoplasma species. Journal of Comparative Pathology 75, 363-374. 
Cottew, G. S., Watson, W. A., Erdag, O. \& Arisoy, F. (1969). Mycoplasmas of caprine pleuropneumonia in Turkey and their relationship to other mycoplasmas of goats and M. mycoides var. mycoides. Journal of Comparative Pathology 79, 54I-55I.

Del Giudice, R. A., Robillard, N. F. \& Carski, T. R. (1967). Immunofluorescence identification of Mycoplasma on agar by use of incident illumination. Journal of Bacteriology 93, 1 $205-1209$.

Dinter, Z., Danielsson, D. \& Bakos, K. (I965). Differentiation of porcine Mycoplasma strains. Journal of General Microbiology 4r, 77-84.

EDWARD, D. G. FF. (1953). Organisms of the pleuropneumonia group causing disease in goats. The Veterinary Record 65, 873-874.

EDWARD, D. G. FF. (1954). The pleuropneumonia group of organisms: a review together with some new observations. Journal of General Microbiology ro, 27-64.

EDWARD, D. G. FF. (1955). A suggested classification and nomenclature for organisms of the pleuropneumonia group. International Bulletin of Bacteriological Nomenclature and Taxonomy 5, 85-93.

EdWARD, D. G. FF. \& FreUndT, E. A. (1956). The classification and nomenclature of organisms of the pleuropneumonia group. Journal of General Microbiology 14, 197-207.

Edward, D. G. FF. \& Freundt, E. A. (1965). A note on the taxonomic status of strains like 'Campo', hitherto classified as Mycoplasma hominis, type 2. Journal of General Microbiology 41, 263-265.

EdWARD, D. G. FF. \& Freundt, E. A. (1973). Type strains of species of the order Mycoplasmatales, including designation of neotypes for Mycoplasma mycoides subsp. mycoides, Mycoplasma agalactiae subsp. agalactiae, and Mycoplasma arthritidis. International Journal of Systematic Bacteriology 23, 55-6I.

EL NASRI, M. (1967). Mycoplasma from contagious caprine pleuropneumonia. Annals of the New York Academy of Sciences $\mathbf{1 4 3}, 298-304$.

Erno, H., Freundt, E. A., Krogsgandd-Jensen, A. \& Rosendal, S. (1972). The identification of an organism isolated from maned sheep as Mycoplasma mycoides subsp. mycoides. Acta veterinaria scandinavica 13, 263-265.

ERnð, H. \& STIPkovits, L. (I973). Bovine mycoplasmas: cultural and biochemical studies. Acta veterinaria scandinavica $\mathbf{4}, 436-449$.

Freundt, E. A., Andrews, B. E., Ernø, H., Kunze, M. \& Black, F. T. (1973). The sensitivity of Mycoplasmatales to sodium-polyanethol-sulfonate and digitonin. Zentralblatt für Bakteriologie, Parasitenkunde, Infektionskrankheiten und Hygiene (Abteilung I) 225, I04-I 12.

Hudson, J. R., CotTew, G. S. \& Adler, H. E. (1967). Disease of goats caused by Mycoplasma; a review of the subject with some new findings. Annals of the New York Academy of Sciences 143, 287-297.

JonAs, A. M. \& BARber, T. L. (I969). Mycoplasma mycoides var. capri isolated from a goat in Connecticut. Journal of Infectious Diseases 1 r9, I 26-I 3 I.

Kelton, W. H. \& MANDEL, M. (I969). Deoxyribonucleic acid base compositions of Mycoplasma strains of avian origin. Journal of General Microbiology 56, I 3 I-I 35.

LAws, L. (1956). A pleuropneumonia-like organism causing peritonitis in goats. The Australian Veterinary Journal 32, 326-329.

LEMCKE, R. M. (1964). The serological differentiation of Mycoplasma strains (pleuropneumonia-like organisms) from various sources. Journal of Hygiene 62, 199-2 19.

LEMCKE, R. M. (I974). The relationship of a caprine mycoplasma to PG3, the type strain of Mycoplasma mycoides subsp. capri. Research in Veterinary Sciences $16,119-122$.

Lloyd, L. C. (1970). Subcutaneous lesions induced in rabbits by Mycoplasma mycoides. Journal of Comparative Pathology 80, 195-209.

MANCHEE, R. J. \& TAYLOR-ROBINSON, D. (1968). Haemadsorption and haemagglutination by mycoplasmas. Journal of General Microbiology 50, 465-478.

Morton, H. E. (1970). Mycoplasmas from man with undetermined specific relationships to their human host. In The Role of Mycoplasmas and L Forms of Bacteria in Disease, chapter 8. Edited by J. T. Sharp. Springfield, Illinois: C. C. Thomas.

Morton, H. E. \& Roberts, R. J. (1967). Properties of Mycoplasma hominis 4330. Journal of Bacteriology 93, 7 I I-7I5.

Neimark, H. C. (1967). Heterogeneity among the Mycoplasma and relationships to bacteria. Annals of the New York Academy of Sciences 143, 3I-37.

NeImARK, H. C. (1970). Division of Mycoplasma into subgroups. Journal of General Microbiology 63, 249263.

Neimark, H. C. \& Pene, J. J. (I965). Characterization of pleuropneumonia-like organisms by deoxyribonucleic acid composition. Proceedings of the Society for Experimental Biology and Medicine 118, 51 7-519. 
Neimark, H. C. \& Pickett, M. J. (1960). Products of glucose metabolism by pleuropneumonia-like organisms. Annals of the New York Academy of Sciences 79, 531-537.

Pearson, J. E., Rokey, N. W., Harrington, R., Proctor, S. J. \& Cassidy, D. R. (i972). Contagious caprine pleuropneumonia in Arizona. Journal of the American Veterinary Medical Association r6r, I 536-1 538.

Perreau, P. (197I). Identification de certaines souches de mycoplasmes de la chèvre a l'espèce Mycoplasma mycoides var. mycoides. Revue d'élevage et de médecine vétérinaire des pays Tropicaux 24, 343-348.

Popkin, T. J., Theodore, T. S. \& Cole, R. M. (1971). Electron microscopy during release and purification of mesosomal vesicles and protoplast membranes from Staphylococcus aureus. Journal of Bacteriology 107, 907-917.

Purcell, R. H., Taylor-Robinson, D., Wong, D. C. \& Chanock, R. M. (1966). A color test for the measurement of antibody to the non-acidforming human Mycoplasma species. American Journal of Epidemiology 84, 5I-66.

Razin, S. (1968). Mycoplasma taxonomy studied by electrophoresis of cell proteins. Journal of Bacteriology 96, 687-694.

Razin, S. \& Cleverdon, R. C. (1965). Carotenoids and cholesterol in membranes of Mycoplasma laidlawii. Journal of General Microbiology 4r, 409-4I 5.

RAZIN, S. \& RotTEM, S. (1967). Identification of Mycoplasma and other micro-organisms by polyacrylamide gel electrophoresis of cell proteins. Journal of Bacteriology 94, 1807-1810.

Razin, S. \& Tully, J. G. (1970). Cholesterol requirement of mycoplasmas. Journal of Bacteriology I02, 306-310.

RotTeM, S. \& RAZIN, S. (1967). Electrophoretic patterns of membrane proteins of Mycoplasma. Journal of Bacteriology 94, 359-364.

RYAN, J. L. \& MOROWITZ, H. J. (1969). Partial purification of native rRNA and tRNA cistrons from Mycoplasma sp. (kid). Proceedings of the National Academy of Sciences of the United States of America 63, I 282-1 289 .

Subcommittee on TAXonomy of the Mycoplasmatales (1972), Proposals for minimal standards for descriptions of new species of the order Mycoplasmatales. International Journal of Systematic Bacteriology 22, I $84-188$.

Sullivan, N. D., St George, T. D. \& Horsfall, N. (1973). A proliferative interstitial pneumonia of sheep associated with mycoplasma infection. Australian Veterinary Journal 49, 57-68.

Taylor-Robinson, D., Purcell, R. H., Wong, D. C. \& Chanock, R. M. (I966). A color test for the measurement of antibody to certain Mycoplasma species based upon the inhibition of acid production. Journal of Hygiene 64, 9I-104.

Theodore, T. S., King, J. R., Tully, J. G. \& Cole, R. M. (1970). Polyacrylamide gel patterns of microorganisms. In Developments in Industrial Microbiology, chapter I4, vol. II, Edited by C. Corum. Washington, D.C.: American Institute of Biological Sciences.

TourtellotTe, M. E. \& JACOBS, R. E. (1960). Physiological and serologic comparisons of PPLO from various sources. Annals of the New York Academy of Sciences 79, 52 I-530.

TúlY, J. G. (1965). Biochemical, morphological, and serological characterization of Mycoplasma of murine origin. Journal of Infectious Diseases $115,17 \mathrm{I}-185$.

Williams, C. O. \& WitTler, R. G. (I97I). Hydrolysis of aesculin and phosphatase production by members of the order Mycoplasmatales which do not require sterol. International Journal of Systematic Bacteriology 21, 73-77.

Williams, C. O., Wittler, R. G. \& Burris, C. (1969). Deoxyribonucleic acid base compositions of selected mycoplasmas and L-phase variants. Journal of Bacteriology 99, 34I-343.

Yedloutschnig, R. J., TAYlor, W. D. \& DARdiri, A. H. (I971). Isolation of Mycoplasma mycoides var. capri from goats in the United States. Proceedings of the U.S. Animal Health Association 75, 166-1 75. 